\title{
Application of Metric System for Individualization from Lip Prints
}

\author{
Palak Gupta and Amit Chauhan* \\ Amity Institute of Forensic Sciences, Amity University, India
}

Submission: April 10, 2018; Published: April 23, 2018

*Corresponding author: Amit Chauhan, Amity Institute of Forensic Sciences, Amity University, Sec-125 Noida, Uttar Pradesh, INDIA Sec-125 Noida, Uttar Pradesh, INDIA Email: amit_chauhan777@yahoo.in

\begin{abstract}
In forensic science, the main framework of an investigator is to deal with the distinct types of evidences and to reveal the identity of an individual/suspect. These evidences may be in form of physical, biological or chemical forms. The evidences are recovered in various forms such as patent, latent, plastics or in semi-visible forms. A few of the evidences which are observed in physical forms but also carry the biological substantial in form of DNA along with it. It includes the latent fingerprints, palm prints, lip prints, ear prints etc. Similar like the palmar surface, the lip prints are also considered perpetual, unique to an individual. The furrows or wrinkles make if different from other individuals for identification. This study was conducted to conclude the identity of suspect/accused by using the metric system. To conclude the identity, six parameters were fixed along an intensified lip print over documents. As a resultant of this study, four parameters concluded the identification of suspect at $\mathrm{p}<0.10$ confidence level. While two parameters present the symptoms of variation in the implementation of lip print over the surface. The result of this study can use to nab the suspect and put them in the judicial system.
\end{abstract}

Keywords : Metric system; Identification; Lip prints; Crime scene; Gender Discrimination etc

\section{Introduction}

In forensic field, a rapid change in the technology of investigation has taken place. New investigative expanses and sources are making the investigation more specific and individualize. Since when, DNA has been explored and unequivocal to an individual. Dental, fingerprint and DNA comparisons are probably the most common techniques used in this context, allowing fast and reliable identification process [1]. Yet another aspect such as palmar surface, planter surface, labial mucosa etc. exists and that are considered exclusive, perpetual, and ubiquitous by nature; has proven their feasibility in this field. Similar like of finger prints, lip prints have also proven it feasibility in forensic investigation in form of a individualize feature [2]. Zone and in between the inner labial mucosa and outer skin of a human lip. The lip prints consist of cracks in form of elevation and depressions which present the fingerprints of an individual [3].

Figure 1: Lip prints present in collar of a shirt. 
Lip prints can be identified in the sixth week of intrauterine life and their pattern is rarely changed. Minor trauma such as inflammation or herpes, will not have a pronounced effect on the appearance of the lips and adjacent tissues, while greater trauma such as surgical treatments and scarring may affect the size and shape of the morphology of the lips. Lip prints of parents and children as well as those of brothers and sisters show some similarities. In 1902, R. Fischer was the first person to identify the exclusive features the lip prints and described it [4 ]. Le Moyne Synder followed his work and introduced a concept of utilization of wrinkles and grooves of the lip prints for identification in 1950 [5]. According to these researchers, lip prints were divided into four blazons namely straight lines, curved lines, angled and sine shaped curve. In addition of their work, Suzuki and Tsuchihashi classified the lip prints into clear cut groove, branched groove, intersected groove, reticular type $\mathrm{V}$ pattern etc. The imprint of lips is considered analogous to the fingerprint. The prints found at a crime scene can establish a scientific basis for identification. The assumption behind this is that; they would reveal the nature of crime, the number of people involved in it, the gender, the use of cosmetics as well as habits, occupational characteristics and the pathological changes of the lips themselves. In practice, the imprint of the lips can be found on the surface of the window, painting, doors, plastic bags, cigarette butts, etc. finding lip prints is not difficult Figure 1.

\section{Potentiality of lip prints at distinctive surfaces}

Lip prints are recovered in static, half static or dynamic form from the scene of occurrence. Static and half static prints reveal their identity in form of the classified features while dynamic is found in smudged form. The identification from dynamic prints are impossible. Lip prints are infallible which means incapable of being wrong in personal identification of individual. It offers positive error free results for identification of culprits found at several objects at crime scene $[9,10]$.

\section{Implication}

Forensic science refers to scientific fields and disciplines that can be used in the court and have been generally accepted as reliable both by trial judges and by the relevant scientific community to distinguish truth from falsehood [8].This study was conducted to determine the individuality from the lip prints present on various surfaces $[11,12]$. At other instance, the level of variation was also determined. However, studying in depth and establishing the facts and truth of Lip prints will certainly help as useful evidence in forensic dentistry. In the process of identification, the oral cavity allows countless possibilities yet more researches need to be conducted regardless for the confirmation of uniqueness and to interpret the important of such evidences [9].

\section{Methodology}

In this pilot study, 50 samples including male and females were collected from Amity institute of forensic Sciences, Amity
University from age group of 18-25 years. First time sampling was done in January 2018 approximate temperature 3-15 0C, while the second time samples were collected from same individuals in March 2018 at an approximate temperature 15-26 $0 \mathrm{C}$. The sample selection was done randomly and the consent of the subjects was taken earlier. Subjects with any kind of injury of vermillion zone or disease were excluded from samples Figure 2.

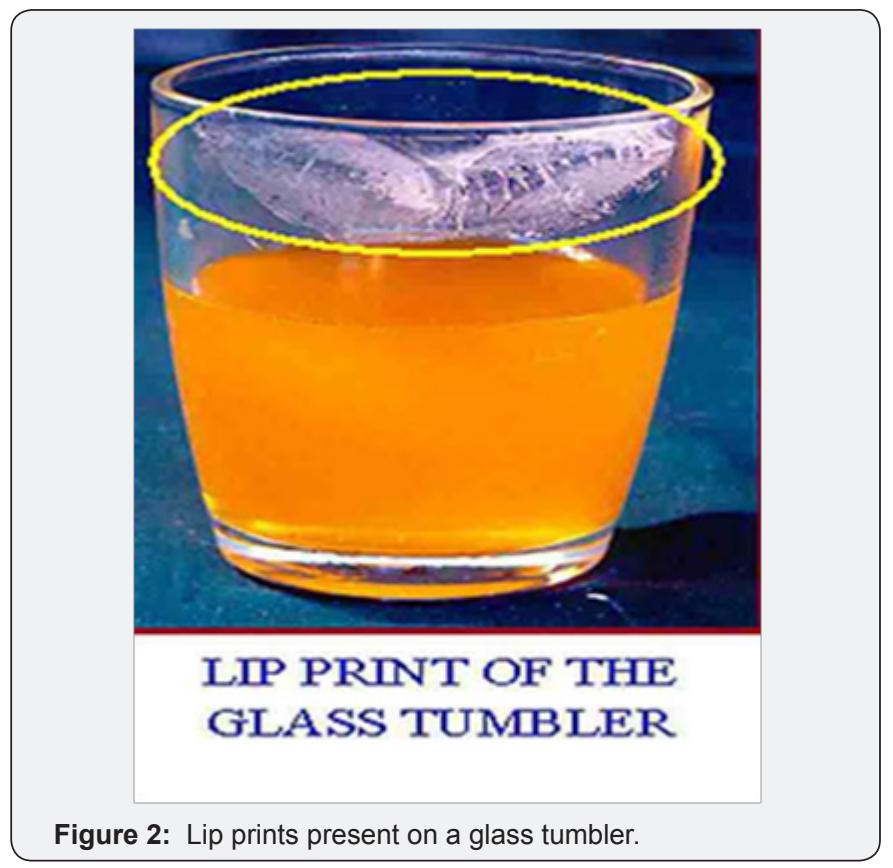

\section{Material}

All the samples were collected on A4 size white paper sheet with the help of coloured material i.e. lipstick, lip glue etc. After the application of material over lip prints, individuals were asked to implement their prints over paper sheet. Collected samples were preserved in simple brown paper envelope to prevent them from the atmospheric moisture or foreign ingredients. The both samples (fresh and old) were analysed for individualization. For which six parameters were fixed in lip prints. During the analysis of samples stereoscope including hand lens of $5 \mathrm{x}$ and $10 \mathrm{x}$ were used. All samples were photographed by Oppo A5 smart phone of 16 megapixels camera. For the calculation, SPSS latest version 17.0 along with MS excels was used. To conclude the individuality of the suspect/individual, two-tailed fashion t-test was embedded in this study. A hypothesis was set for both parameters in which, it is estimated that $\mathrm{H} 0$ is rejected in favour of Ha [10].

\section{Result and Discussion}

Most often, the individual and class features of lip prints are studied for the establishment of individuality. The lip prints can be observed in several predicaments i.e. static, half static or dynamic form and the identity are left questionable. Since the interpersonal and interpretational variations come in, therefore, the methods were adopted to turn out the involvement of an individual in a crime. The collected samples analysed dossier are 
given below in Table 1. As a resultant of this study, it was observed that both of the samples provide the significant similarity were observed with minimum standard error in the measurements. At first parameter (total dimension of li prints), the mean values are 4.31 and 4.3 with standard errors 0.07 and -0.139 . The standard deviation values for both samples are quite similar 0.351 and 0.356 respectively. While at the second parameter (inner breadth), the means values are 4.63 and 4.69 which is the representation of variation at the time of implementation of lip prints. The standard deviation values are 0.497 and 0.462 at std. error rate of 0.101 and -0.491 . While at the third and fourth parameter (Inner width of lip prints and parallel inner width), the means values are 2.4, 3.2 and for exemplar; values are 2.6 and 3.2 which gives an indication of natural variation. All the values were obtained at a minimum standard error $0.09,0.117$ and $-0.339,0.151 \mathrm{~cm}$ Figure 3.

Table 1: measurements of lip prints at various parameters.

\begin{tabular}{|c|c|c|c|c|c|c|}
\hline Sample NO. & $\begin{array}{l}\text { Total dimension } \\
\text { of lip print }(\mathrm{cm} \text {.) }\end{array}$ & $\begin{array}{l}\text { Inner breadth } \\
\text { (cm.) }\end{array}$ & $\begin{array}{l}\text { Width of lip } \\
\text { prints } \\
\text { (cm.) }\end{array}$ & $\begin{array}{l}\text { Inner width } \\
\text { (cm.) }\end{array}$ & $\begin{array}{c}\text { Angle of lip print } \\
\text { from the right } \\
\text { joint } \mathrm{C}^{0}\end{array}$ & $\begin{array}{l}\text { Angle of lip print } \\
\text { from the left } \\
\text { joint } D^{0}\end{array}$ \\
\hline 1 & $4.7 \mathrm{~cm}$ & $5 \mathrm{~cm}$ & $3 \mathrm{~cm}$ & $3.4 \mathrm{~cm}$ & $60^{\circ}$ & $60^{\circ}$ \\
\hline 2 & $4.1 \mathrm{~cm}$ & $4.5 \mathrm{~cm}$ & $2.1 \mathrm{~cm}$ & $2.8 \mathrm{~cm}$ & $60^{\circ}$ & $60^{\circ}$ \\
\hline 3 & $3.7 \mathrm{~cm}$ & $4.1 \mathrm{~cm}$ & $2.5 \mathrm{~cm}$ & $2.2 \mathrm{~cm}$ & $64^{\circ}$ & $65^{\circ}$ \\
\hline 4 & $3.9 \mathrm{~cm}$ & $4.3 \mathrm{~cm}$ & $1.9 \mathrm{~cm}$ & $2.9 \mathrm{~cm}$ & $68^{\circ}$ & $64^{\circ}$ \\
\hline 5 & $4.4 \mathrm{~cm}$ & $5.2 \mathrm{~cm}$ & $2.1 \mathrm{~cm}$ & $4.1 \mathrm{~cm}$ & $54^{\circ}$ & $60^{\circ}$ \\
\hline 6 & $4.1 \mathrm{~cm}$ & $4.5 \mathrm{~cm}$ & $2.6 \mathrm{~cm}$ & $3.7 \mathrm{~cm}$ & $67^{\circ}$ & $70^{\circ}$ \\
\hline 7 & $4.4 \mathrm{~cm}$ & $5.1 \mathrm{~cm}$ & $2.1 \mathrm{~cm}$ & $3.8 \mathrm{~cm}$ & $64.5^{\circ}$ & $69^{\circ}$ \\
\hline 8 & $3.2 \mathrm{~cm}$ & $4.9 \mathrm{~cm}$ & $1.4 \mathrm{~cm}$ & $2.5 \mathrm{~cm}$ & $62^{\circ}$ & $62.5^{\circ}$ \\
\hline 9 & $3.9 \mathrm{~cm}$ & $5 \mathrm{~cm}$ & $2.9 \mathrm{~cm}$ & $3.4 \mathrm{~cm}$ & $62^{\circ}$ & $64^{\circ}$ \\
\hline 10 & $3.9 \mathrm{~cm}$ & $5 \mathrm{~cm}$ & $2.9 \mathrm{~cm}$ & $3.4 \mathrm{~cm}$ & $65^{\circ}$ & $64^{\circ}$ \\
\hline 11 & $4.5 \mathrm{~cm}$ & $5.7 \mathrm{~cm}$ & $3.1 \mathrm{~cm}$ & $4.6 \mathrm{~cm}$ & $60^{\circ}$ & $62^{\circ}$ \\
\hline 12 & $3.9 \mathrm{~cm}$ & $4.8 \mathrm{~cm}$ & $2 \mathrm{~cm}$ & $3 \mathrm{~cm}$ & $63^{\circ}$ & $65^{\circ}$ \\
\hline 13 & $4.2 \mathrm{~cm}$ & $4.9 \mathrm{~cm}$ & $2.7 \mathrm{~cm}$ & $3.5 \mathrm{~cm}$ & $63.5^{\circ}$ & $65^{\circ}$ \\
\hline 14 & $4.1 \mathrm{~cm}$ & $4.9 \mathrm{~cm}$ & $2.6 \mathrm{~cm}$ & $3.5 \mathrm{~cm}$ & $64^{\circ}$ & $68^{\circ}$ \\
\hline 15 & $4.3 \mathrm{~cm}$ & $4.3 \mathrm{~cm}$ & $2.9 \mathrm{~cm}$ & $3.1 \mathrm{~cm}$ & $61^{\circ}$ & $65^{\circ}$ \\
\hline 16 & $4.6 \mathrm{~cm}$ & $3.9 \mathrm{~cm}$ & $2.7 \mathrm{~cm}$ & $2.5 \mathrm{~cm}$ & $67^{\circ}$ & $65^{\circ}$ \\
\hline 17 & $3.9 \mathrm{~cm}$ & $4.4 \mathrm{~cm}$ & $2.7 \mathrm{~cm}$ & $3.6 \mathrm{~cm}$ & $65^{\circ}$ & $69^{\circ}$ \\
\hline 18 & $4.3 \mathrm{~cm}$ & $4.4 \mathrm{~cm}$ & $1.8 \mathrm{~cm}$ & $3.2 \mathrm{~cm}$ & $64^{\circ}$ & $68^{\circ}$ \\
\hline 19 & $3.8 \mathrm{~cm}$ & $4.8 \mathrm{~cm}$ & $1.6 \mathrm{~cm}$ & $2.8 \mathrm{~cm}$ & $63^{\circ}$ & $70^{\circ}$ \\
\hline 20 & $4.4 \mathrm{~cm}$ & $4.3 \mathrm{~cm}$ & $2.1 \mathrm{~cm}$ & $3.3 \mathrm{~cm}$ & $72^{\circ}$ & $72^{\circ}$ \\
\hline 21 & $4 \mathrm{~cm}$ & $5 \mathrm{~cm}$ & $2.3 \mathrm{~cm}$ & $3.7 \mathrm{~cm}$ & $69^{\circ}$ & $70^{\circ}$ \\
\hline 22 & $4.7 \mathrm{~cm}$ & $5.2 \mathrm{~cm}$ & $2.5 \mathrm{~cm}$ & $3.4 \mathrm{~cm}$ & $62^{\circ}$ & $61^{\circ}$ \\
\hline 23 & $4.3 \mathrm{~cm}$ & $4.1 \mathrm{~cm}$ & $2.6 \mathrm{~cm}$ & $3.2 \mathrm{~cm}$ & $60^{\circ}$ & $62^{\circ}$ \\
\hline 24 & $3.6 \mathrm{~cm}$ & $3.4 \mathrm{~cm}$ & $2.3 \mathrm{~cm}$ & $2.9 \mathrm{~cm}$ & $71^{\circ}$ & $67^{\circ}$ \\
\hline 25 & $4.4 \mathrm{~cm}$ & $4.1 \mathrm{~cm}$ & 3.1 & 1.9 & $65^{\circ}$ & $65^{\circ}$ \\
\hline
\end{tabular}




\section{Journal of Forensic Sciences \& Criminal Investigation}

Every individual has distinguished way to implement their lip print over any object, that makes it differ from others. The fifth and sixth parameter of lip print (Angle of lip print from right side, angle of lip prints from left side) are <C 64 OC and 65 0C while for angle $<$ D, the values are $66.50 \mathrm{C}$ and $680 \mathrm{C}$. In the study Table 2: Statistical analysis of table No 1. of these parameters, a range of variation was observed which is an indication human resources not a machine or any kind of forgery. During the analysis of these parameters, standard error is noticed which is $<$ C $0.70 \mathrm{C}$ and $<$ D $0.20 \mathrm{C}$ Table 2 .

\begin{tabular}{|c|c|c|c|c|c|c|}
\hline S NO. & $\begin{array}{c}\text { Total } \\
\text { dimension of } \\
\text { lip print(cm.) }\end{array}$ & $\begin{array}{c}\text { Inner breadth } \\
\text { (cm.) }\end{array}$ & $\begin{array}{c}\text { Width of lip } \\
\text { prints (cm.) }\end{array}$ & $\begin{array}{c}\text { Inner width } \\
\text { (cm.) }\end{array}$ & $\begin{array}{c}\text { Angle of lip } \\
\text { print from the } \\
\text { right joint C0 }\end{array}$ & $\begin{array}{c}\text { Angle of lip } \\
\text { print from the } \\
\text { left joint D0 }\end{array}$ \\
\hline Mean & 4.132 & 4.63 & 2.42 & 3.21 & 63.84 & 65.3 \\
\hline Variance & 0.1245 & 0.247 & 0.211 & 0.334 & 14.39 & 11.76 \\
\hline S.D. & 0.3529 & 0.497 & 0.459 & 0.578 & 3.793 & 3.429 \\
\hline Skewness & -0.4837 & -0.291 & -0.395 & -0.07 & -0.022 & 0.130 \\
\hline S.Error & 0.07 & 0.101 & 0.093 & 0.117 & 0.77 & 0.7 \\
\hline
\end{tabular}

The significance level of the study was observed at $\mathrm{p}<0.10$ confidence level. The obtained result of exemplar from the use of six parameters was highly conclusive. Out of six parameters, four

Table 3: measurements of specimen lip prints at various parameters.

\begin{tabular}{|c|c|c|c|c|c|c|}
\hline Sample NO. & $\begin{array}{l}\text { Total dimension } \\
\text { of lip print }(\mathrm{cm} \text {.) }\end{array}$ & $\begin{array}{l}\text { Inner breadth } \\
\text { (cm.) }\end{array}$ & $\begin{array}{l}\text { Width of lip } \\
\text { prints } \\
\text { (cm.) }\end{array}$ & $\begin{array}{l}\text { Inner width } \\
\text { (cm.) }\end{array}$ & $\begin{array}{l}\text { Angle of lip print } \\
\text { from the right } \\
\text { joint } \mathrm{CO}\end{array}$ & $\begin{array}{l}\text { Angle of lip print } \\
\text { from the left } \\
\text { joint D0 }\end{array}$ \\
\hline 1 & 1 & 4.9 & 5.1 & 2.8 & $3.5^{\circ}$ & $62^{\circ}$ \\
\hline 2 & 2 & 4.3 & 4.6 & 2.4 & $2.7^{\circ}$ & $63^{\circ}$ \\
\hline 3 & 3 & 3.9 & 4.4 & 2.7 & $2.4^{\circ}$ & $69^{\circ}$ \\
\hline 4 & 4 & 4.0 & 4.2 & 3.0 & $2.7^{\circ}$ & $68^{\circ}$ \\
\hline 5 & 5 & 4.5 & 5.3 & 2.2 & $3.9^{\circ}$ & $58^{\circ}$ \\
\hline 6 & 6 & 4.4 & 4.7 & 2.8 & $3.9^{\circ}$ & $70^{\circ}$ \\
\hline 7 & 7 & 4.2 & 5.0 & 2.2 & $4.0^{\circ}$ & $67^{\circ}$ \\
\hline 8 & 8 & 3.5 & 5.1 & 1.7 & $2.6^{\circ}$ & $63^{\circ}$ \\
\hline 9 & 9 & 4.1 & 5.2 & 3.1 & $3.2^{\circ}$ & $70^{\circ}$ \\
\hline 10 & 10 & 3.8 & 5.1 & 3.2 & $3.1^{\circ}$ & $65^{\circ}$ \\
\hline 11 & 11 & 4.6 & 5.5 & 3.4 & $4.8^{\circ}$ & $72^{\circ}$ \\
\hline 12 & 12 & 4.0 & 4.9 & 2.1 & $3.2^{\circ}$ & $72^{\circ}$ \\
\hline 13 & 13 & 4.5 & 4.6 & 3.0 & $3.6^{\circ}$ & $58^{\circ}$ \\
\hline 14 & 14 & 4.2 & 5.0 & 2.7 & $3.7^{\circ}$ & $70^{\circ}$ \\
\hline 15 & 15 & 4.5 & 4.4 & 3.0 & $3.3^{\circ}$ & $65^{\circ}$ \\
\hline 16 & 16 & 4.7 & 4.1 & 2.9 & $2.6^{\circ}$ & $75^{\circ}$ \\
\hline 17 & 17 & 4.0 & 4.5 & 2.8 & $3.7^{\circ}$ & $55^{\circ}$ \\
\hline 18 & 18 & 4.5 & 4.1 & 2.2 & $3.3^{\circ}$ & $69^{\circ}$ \\
\hline 19 & 19 & 4.1 & 4.9 & 1.9 & $3.0^{\circ}$ & $63^{\circ}$ \\
\hline 20 & 20 & 4.5 & 4.5 & 2.3 & $3.5^{\circ}$ & $72^{\circ}$ \\
\hline 21 & 21 & 4.2 & 5.1 & 2.5 & $3.8^{\circ}$ & $72^{\circ}$ \\
\hline 22 & 22 & 5.0 & 5.0 & 2.9 & $3.5^{\circ}$ & $60^{\circ}$ \\
\hline 23 & 23 & 4.5 & 4.3 & 2.8 & $3.4^{\circ}$ & $75^{\circ}$ \\
\hline 24 & 24 & 3.7 & 3.5 & 2.4 & $3.1^{\circ}$ & $64^{\circ}$ \\
\hline 25 & 25 & 4.5 & 4.2 & 3.3 & $2.1^{\circ}$ & $67^{\circ}$ \\
\hline
\end{tabular}

parameters were providing significant values for identification. the significant table are given below in Table 3 . 


\section{Journal of Forensic Sciences \& Criminal Investigation}

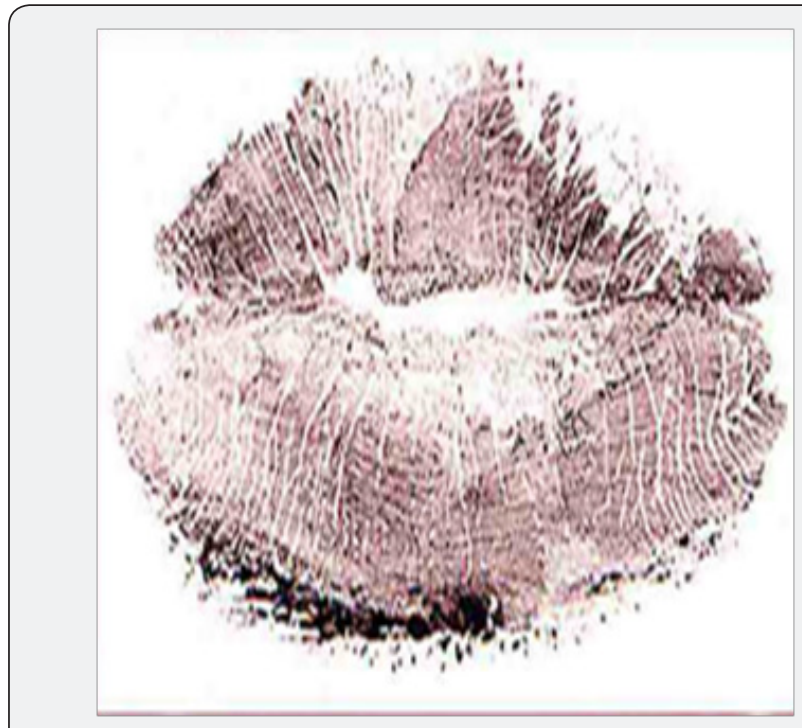

Figure 4: Lip print present on a white sheet paper.

During the analysis of lip print from fresh sample and old sample in parameter one (total dimension of lip print), the obtained T Value was -1.4847 and P Value was 0.072 which is significant as $0.072<\mathrm{p}<0.10$. it prefers that the parameter is capable to conclude the identity of suspect/individual. While at the second parameter (Inner breadth of lip print) the obtained $T$ Value was -0.432 and $P$ Value was 0.333 which is not significant at $0.333>p<0.10$ level of confidence. It can occur due to variation in the implementation of lip prints at object. The third parameter (Width of lip print) provides the $\mathrm{T}$ Value $(-1.796)$ and $\mathrm{P}$ Value was .039 which is significant $0.039<\mathrm{p}<0.10$ at confidence level Figure 4 [11-13].

At the fourth parameter (Inner width of lip prints) gives the $\mathrm{T}$-value (0.526) and the p-value was (0.300). the obtained values are not significant $0.039>\mathrm{p}<0.10$ and concludes that this parameter may provide the variation in implementation of lip prints. The Fifth diameter (Angle from the right joint of lip prints) provides the significant value T-Value was -1.32 and $p$-value (0.019). The obtained value $0.019<p<0.10$ is significant while on the other end, at the same fixed parameter of angle from the left joint of lip print; T- value is -1.024 and $p$ - value is 0.023 . The obtained value $0.023<\mathrm{p}<0.10$ is significant. During this study, it was observed that for last parameters are significant. It is an indication that an individual implements their lip prints in same formation (angle), it only differs in dimensions i.e. breadth, width etc Table $4 \& 5$.

Table 4: Statistical analysis of table no. 3.

\begin{tabular}{|c|c|c|c|c|c|c|}
\hline S NO. & $\begin{array}{c}\text { Total dimension } \\
\text { of lip print(cm.) }\end{array}$ & $\begin{array}{c}\text { Inner breadth } \\
\text { (cm.) }\end{array}$ & $\begin{array}{c}\text { Width of lip } \\
\text { prints (cm.) }\end{array}$ & $\begin{array}{c}\text { Inner width } \\
\text { (cm.) }\end{array}$ & $\begin{array}{c}\text { Angle of lip print } \\
\text { from the right } \\
\text { joint C0 }\end{array}$ & $\begin{array}{c}\text { Angle of lip print } \\
\text { from the left } \\
\text { joint D0 }\end{array}$ \\
\hline Mean & 4.28 & 4.69 & 2.65 & 3.30 & 66.56 & 68.24 \\
\hline Variance & 0.126 & 0.213 & 0.188 & 0.335 & 28.166 & 22.102 \\
\hline S.D. & 0.356 & 0.462 & 0.434 & 0.579 & 5.307 & 4.701 \\
\hline Skewness & 0.072 & 0.094 & 0.088 & 0.118 & 1.083 & 0.959 \\
\hline S.Error & -0.139 & -0.491 & -0.339 & 0.151 & -0.357 & 0.299 \\
\hline
\end{tabular}

Table 5: Statistical significance level of the lip prints between questioned and specimen samples.

\begin{tabular}{|c|c|c|c|c|c|c|}
\hline S NO. & $\begin{array}{c}\text { Total dimension } \\
\text { of lip print(cm.) }\end{array}$ & $\begin{array}{c}\text { Inner breadth } \\
\text { (cm.) }\end{array}$ & $\begin{array}{c}\text { Width of lip } \\
\text { prints (cm.) }\end{array}$ & $\begin{array}{c}\text { Inner width } \\
\text { (cm.) }\end{array}$ & $\begin{array}{c}\text { Angle of lip print } \\
\text { fromtheright } \\
\text { joint Co }\end{array}$ & $\begin{array}{c}\text { Angle of lip print } \\
\text { from the left } \\
\text { joint D0 }\end{array}$ \\
\hline T-value & -1.4847 & -0.432 & -1.796 & 0.526 & -1.320 & -1.0245 \\
\hline P-Value & 0.072 & 0.333 & .039 & 0.300 & 0.019 & 0.023 \\
\hline Significance & $\mathrm{Y}$ & $\mathrm{N}$ & $\mathrm{Y}$ & $\mathrm{N}$ & $\mathrm{Y}$ & $\mathrm{Y}$ \\
\hline
\end{tabular}

\section{Conclusion}

Establishment of individuality has become an essential in forensic investigation. Now a day, it is possible from various sources of evidences i.e. blood, saliva, sweat urine etc. yet another source is often looked. To identify the suspect from lip prints has not such a long history still it is emerging very rapidly. Similar like of fingerprints, the identification can be done by using the class characteristics as well as from individual that is admissible in court of law under article 6 of Universal declaration of human right. As in this study, individualisation was constituted from lip prints by applying metric system which can play a significant role in solving the crime in the fourth coming time. By using this evidence, the positive identification was ensconced as a mean of identity which can be used as a reliable forensic tool [13]. By considering its consistency over the time and the accurate correlation of indirect points, it is observed that no similarity was found between the lip prints. It offers the positive and error free results for identification of culprits at crime scene. Therefore, it can be a milestone in the field of investigation and to nab the suspects from the objects consisting lip prints recovered from crime scene.

\section{References}

1. Kasprzak J (1990) Possibilities of Cheiloscopy. Forensic Science International, 145-151. 
2. Kim JO, Baik KS, Chung CH (2003) On a Lip Print Recognition by the Pattern Kernel with Multi-resolution Architecture. Lecture Notes in Computer Science, 561-568.

3. Amit Chauhan, Jyoti Singh (2014) Identification of an individual from the latent palm prints present on documents. International journal of Research Science \& Innovation, Vol I Issue VII, 29-35.

4. Russell LW, Welch AE (1984) Analysis of Lipsticks. Forensic Science International, 105 -116.

5. Amit Chauhan, Jyoti Singh, KPS Kushwaha (2015) An Evaluation; Sexing from the Ridge density of latent palm prints of North Indian population. Research Journal of Recent Science, 4:73-75 .

6. Segui MA, Feucht MM, Ponce AC, Pascual FAV (2000) Persistent Lipsticks and Their Lip Prints: new hidden evidence at the crime scene. Forensic Science International, 41- 47.

7. Suzuki K, Tsuchihashi Y (1970) Personal Identification by Means of Lip Prints. Journal of Forensic Medicine, 52- 57.

8. Amit Chauhan, Aditi Chauhan, Jyoti Singh, SK Shukla (2017) A correlative study between the implementation of rhythemic system and hieroglyphissubstantials. International Journal of current research and review. 9 (9): 1-5.

9. Amit Chauhan, Aparna Gautam, Sourabh Kumar Singh, Dr SK Shukla (2017) Gender inequity from the quadrant of lateral fingerprints among the age group of 18-25 years from the population of National capital region of India. International journal of civil engineering and technology. 8 (4): 1402-1407.

10. Tsuchihashi Y (1974) Studies on Personal Identification by Means of Lip Prints. Forensic Science, 233 - 248.

11. Suzuki K, Suzuki H, Tsuchihashi Y (1967) On the female lips and rouge. Jpn J Leg Med Vol. 67-471.

12. Amit Chauhan, Varsha Chauhan (2017) An expansion of indented signatures over the credential by the employment of domicilary commodity. International journal of civil enginnering and technology. 8 (4): 1960-1966.

13. Suzuki K, Tsuchihashi Y (1970) A new attempt of personal identification by means of lip print. J Indian Dent Assoc. 42: 8-9.

\section{Your next submission with Juniper Publishers} will reach you the below assets

- Quality Editorial service

- Swift Peer Review

- Reprints availability

- E-prints Service

- Manuscript Podcast for convenient understanding

- Global attainment for your research

- Manuscript accessibility in different formats ( Pdf, E-pub, Full Text, Audio)

- Unceasing customer service

Track the below URL for one-step submission https://juniperpublishers.com/online-submission.php 